\title{
PIAGAM MADINAH \\ SEBAGAI KONSEP BUDAYA \\ DAN PERADABAN
}

\begin{tabular}{|c|c|c|}
\hline \multicolumn{3}{|c|}{ P-ISSN: 2085-4536 | E-ISSN: 2721-7183 } \\
\hline \multicolumn{3}{|c|}{ Link: https://jurnal-stidnatsir.ac.id/index.php/binaummat/article/view/47 } \\
\hline \multicolumn{3}{|c|}{ DOI : https://doi.org/10.38214/jurnalbinaummatstidnatsir.v2i01.47 } \\
\hline Dikirim: 25-03-2019 & Direview: 05-04-2019 & Diterbitkan: 17-04-2019 \\
\hline \multicolumn{3}{|c|}{$\begin{array}{l}\text { LUKMAN } \\
\text { STID Mohammad Natsir, Indonesia } \\
\text { lukman@stidnatsir.ac.id }\end{array}$} \\
\hline
\end{tabular}

\begin{abstract}
ABSTRAK
Tujuan Penelitian: Penelitian ini bertujuan untuk mengungkap Piagam Madinah sebagai konsep budaya dan peradaban. Metode Penelitian: Kualitatif. Hasil Penelitian: Artikel ini mencoba memaparkan Piagam Madinah sebagai konsep budaya dan peradaban. Hasil dari tulisan ini membuktikan bahwa nilai-nilai Islam dalam bentuk Piagama Madinah yang berlaku dalam kehidupan masyarakat Yatsrib itulah yang kemudian mendasari terbentuknya kebudayaan dan peradaban yang tinggi. Diantara nilai-nilai tersebut adalah bahwa Islam menghapuskan kebodohan (buta huruf), Islam merangsang daya observasi untuk memperhatikan dan meneliti alam semesta, Piagam madinah juga membina daya cipta masyarakat, membina bakat dan potensi sehingga seimbang lahir dan batinnya, seimbang ilmu dan akhlaknya, seimbang ikhtiar dan do'anya. Dengan demikian seharusnya ini menjadi kesadaran semua pihak dalam melakukan pengembangan dan pembinaan masyarakat. Bahwa masyarakat madinah yang dibina oleh Rasulullah Shallallahu 'Alaihi wa Sallam adalah contoh masyarakat ideal yang harus di ikuti.
\end{abstract}

Kata Kunci: Piagam, Madinah, Masyarakat Islam, Peradaban, Budaya

\section{PENDAHULUAN}

Kesepakatan atas naskah Piagam Madinah sebagai aturan bersama masyarakat Madinah, menjadi tonggak baru bagi kehidupan umat manusia. Masyarakat yang dibangun oleh Nabi Muhammad Shallallahu 'Alaihi wa Sallam setelah hijrah dari Makkah ke Madinah tersebut merupakan 
cikalbakal peradaban modern yang mengedepankan kebersamaan ketimbang peperangan, menjunjung tinggi nilai-nilai kemanusiaan, dan mengutamakan semangat kebangsaan ketimbang semangat kesukuan maupun kekabilahan. ${ }^{1}$

Terbentuknya masyarakat Madinah yang dibimbing nilai-nilai Islam, merupakan momen historis lahirnya kebudayaan dan peradaban baru yang akan menyinari dunia. Piagam yang disepakati pada tahun pertama hijrah, bertepatan dengan $622 \mathrm{M}$, merupakan undang-undang tertulis yang bertujuan mengikat tali perbedaan antar etnis, keyakinan maupun kesukuan di kalangan masyarakat Madinah. Upaya membangun masyarakat berperadaban modern dengan menjunjung tinggi nilai-nilai kemanusiaan dan keadilan, dipelopori oleh Nabi Muhammad Shallallahu 'Alaihi wa Sallam jauh sebelum deklarasi Universal PBB tentang HAM tahun 1948, Revolusi Prancis 1789 atau lahirnya konstitusi Amerika tahun 1776.

Prof. HAR Gibb dalam bukunya Writher Islam menyebutkan, "Islam itu sesungguhnya lebih dari suatu system agama saja, Islam adalah suatu kebudayaan yang lengkap." Sejarah telah mencatat dengan baik, bangsa manapun yang berjuang demi kelangsungan mereka dengan menghadapi segala hambatan demi mempertahankan eksistensinya, tentupada suatu saat akan mencapai tingkat peradaban yang tinggi, akanmenemukan kebudayaan sendiri. Mereka dapat meberikan "pelajaran kebudayaan" pada bangsa-bangsa lainnya disamping mewariskan budaya kepada bangsa-bangsa setelahnya. Kedatangan Islam sendiri telah merubah secara drastis budaya masyarakat jazirah Arab, yang tadinya biadab, tidak dikenal dan tidak diperhitungkan kemudian menjadi budaya yang diperhitungkan dan diakui perannya dalam sejarah peradaban manusia. Semua ini terjadi karena Islammemang mempunyai potensi membawa penganutnya untuk mencapai peradaban dan kebudayaan yang tinggi. ${ }^{2}$

\section{Piagam Madinah}

\footnotetext{
${ }^{1}$ https://www.neliti.com/id/publications/148595/piagam-madinahkonsensus-masyarakat-pluralis-madinah-dan-makkah-suatu-tinjauan-t

${ }^{2}$ M. Natsir, Percakapan antar Generasi, Pesan Perjuangan Seorang Bapak, Jakarta: DDII dan LABDA, 1989, hlm. 108-109
} 
Piagam Madinah adalah perjanjian yang ditetapkan oleh Nabi Muhammad Shallallahu 'Alaihi wa Sallam setelah hijrah ke Madinah antara beliau bersama kaum Muslimin (Muhajirin dan Anșhar) dengan Yahudi Madinah. Para ahli menyebut beragam naskah politik yang dibuat oleh Rasulullah tersebut, antara lain: W. Montgomery Watt menamainya "The Contitution of Medina", R.A. Nicholson dalam bukunya A literary History of The Arabs menyebutnya "Charter", Majid Khaddury dalam bukunya $W$ ar and Peace in The Low Of Islam menyebut "Treaty", Philip K Hitti dalam bukunya Capital Cities Of Arab Islam "agreement", Zainal Abidin Ahmad menamainya "Piagam"3

Dalam bahasa Arab sendiri yang merujuk kepada kiba Sirah alnabiyy karya Ibn Hisyam, Piagam Mazdinah adalah /șahifatu

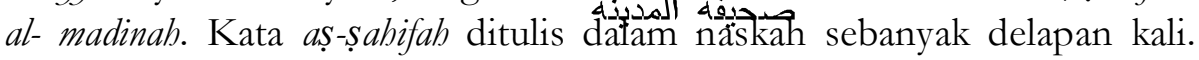
Selain nama itu, di dalam naskah, tertulis sebutan "kitab" dua kali. Kata treaty dan agreement menunjuk kepada isi naskah. Kata charter dan piagam lebih menunjuk pada surat resmi yang berisi pernyataan tentang sesuatu hal. Dan kata șabifah semakna dengan charter atau piagam. ${ }^{4}$

Piagam Madinah terdiri dari 47 pasal, meskipun pada dasarnya dalam teks asli naskah ini tidak terdapat pembagian pasal-pasal. Pemberian pasal- pasal baru kemudian dilakukan oleh para peneliti naskah tersebut, antara lain Dr. A.J.Wensinck dalam bukunya Mobammed en de Yoden te Medina tahun $1928 \mathrm{M}$ dan W. Montgomery Watt dalam bukunya Muhammad at Madina tahun 1956. Sedangkan pembagian bab menjadi 10 bab ditambah mukaddimah dilakukan oleh Zainal Abidin Ahmad dalam Karyanya Piagam Madinab Konstitusi Tertulis Pertama di Dunia. ${ }^{5}$

Pembagian bab-bab yang telah disusun oleh Zainal Abidin Ahmad adalah sebagai berikut:

I. Pembentukan Ummah, terdiri dari pasal 1

II. Hak Asasi manusia, terdiri dari pasal 2 s.d pasal 10

III. Persatuan Seagama, terdiri dari pasal 11 s.d pasal 15

IV. Persatuan SegenapWarga Negara, terdiri dari pasal 16 s.d pasal 23

${ }^{3}$ Ahmad Sukardja, Piagam Madinah \& Undang-Undang Dasar NRI 1954, Jakarta: Sinar Grafika, 2012, hlm. 2

${ }^{4}$ Ibid, hlm. 3

5 Zainal Abidin Ahmad, Piagam Madinah Konstitusi Tertulis Pertama di Dunia, Jakarta: Pustaka Al-Kautsar, 2014, hlm. 11 
V. Golongan Minoritas, terdiri dari pasal 24 s.d pasal 35

VI. Tugas Warga Negara, terdiri dari pasal 36 s.d pasal 38

VII. Melindungi Negara, terdiri dari pasal 39 s.d pasal 41

VIII. Pimpinan Negara, terdiri dari pasal 42 s.d pasal 44

IX. Politik perdamaian, terdiri dari pasal 45 s.d pasal 46

X. Penutup, terdiri dari pasal $47^{6}$

Piagam Madinah secara formal mengatur hubungan sosial antara komponen masyarakat Madinah, yaitu : Pertama, antara sesama muslim, bahwa sesama muslim adalah satu ummat walaupun mereka berbeda suku. Kedua, hubungan antara komunitas muslim dengan non muslim didasarkan pada prinsip "bertetangga yang baik", saling membantu dalam menghadapi musuh bersama, membela mereka yang teraniaya, saling menasihati dan menghormati kebebasan beragama. Konstitusi tersebut telah mengatur tentang hak-hak sipil (civil right) atau lebih dikenal dengan hak asasi manusia (HAM), jauh sebelum deklarasi Universal PBB tentang HAM tahun $1948 .{ }^{7}$

Secara tegas naskah ini menyebutkan bahwa ia adalah suatu "perjanjian masyarakat" yang dituliskan oleh Nabi Muhammad Shallallahu "Alaihi wa Sallam sebagai pemimpin yang memegang amanat, di antara rakyat yang berbagai golongan bangsa dan agama, seperti yang termaktub dalam mukaddimahnya:

"Dengan nama Tuhan Yang Maha Pengasih lagi Maha Penyayang. Inilah Piagam tertulis dari Nabi Muhammad Shallallahu 'Alaihi wa Sallam kepada orang-orang percaya dan memeluk agama Islam, baik yang berasal dari Quraisy maupun Yatsrib, dan kepada segenap warga yang mengikuti mereka, yang telah membentuk kepentingan bersama dengan mereka dan telah berjuang bersama mereka." 8

Di antara para ahli terjadi silang pendapat tentang golongangolongan yang dimaksud dalam piagama ini. Dr. Hasan Ibrahim Hasan menyebutkan 4 golongan yaitu:

1. Muhajirin, yaitu orang-orang islam yang hijrah dari Mekkah;

2. Anshar, yaitu orang-orang Islam dari penduduk Madinah;

\footnotetext{
${ }^{6}$ Ibin, hlm. 12-24

${ }^{7}$ Didin Hafidhuddin, Islam Aplikatif, Jakarta: Gema Insani, 2004, hlm. 98

${ }^{8}$ Zainal Abidin Ahmad, Piagam Madinah Konstitusi Tertulis..., hlm. 115
} 
3. Munafiqun, yaitu penduduk Madinah yang belum memeluk Islam;

4. Yahudi, yaitu kaum yahudi yangtinggal di Madinah. ${ }^{9}$

Demikian juga Emile Dermenghem dalam bukunya Le Vie Mahommet menyebutkan 4 golongan tersebut di atas. Sedangkan Majid Khadduri, George E. Kerk dan Prof. Ahmad Shalaby hanya menyebutkan 3 golongan, yaitu:

1. Muhajirun;

2. Anshar;

3. Yahudi.

Selain itu ada juga penulis tentang piagam Madinah yang memperkecil jumlah itu menjadi 2 golongan, seperti Muhammad Khalid dalam kitabnya Khatam An-Nabiyyin, dan Abdul Muta'al Shu'aidi dalam kitabnya As-Siyasah Al-Islamiyyah hanya menyebut; Kaum Muslimin dan Kaum Yahudi atau Bangsa Arab dan bangsa Yahudi saja. ${ }^{10}$

Piagam Madinah sendiri dalam perkembangannya telah mengalami beberapa kali amandemen, setidaknya Rasulullah Shallallahu 'Alaihi wa Sallam sendiri telah melakukan 2 kali amandemen terhadap Piagam Madinah. Pertama, perlakuan terhadap kaum Kristen, perjanjian dengan kaum Kristen dari najran tahun $625 \mathrm{M}$; terkait pasal 24 s.d pasal 35 berkenaan dengan golongan minoritas; yang sebelumnya hanya ditujukan kepada kaum yahudi, dengan perjanjian ini diperluas menjadi termasuk kaum Nashrani. "keyakinan agama menjalankan amal-amal keagamaannya tidak akan dicampuri; tidak aka nada perubahan atas kebiasaan dan hakhaknya, dan tak seorang pun bshop atau pendeta yang dicabut jabatannya." Kedua, perjanjian dengan kaum Majusi, dilakukan dengan Farrukh bin Syaksan, kepala daerah Yaman yang beragama Majusi. Perjanjian ini juga terkait pasal 24 s.d. pasal 35 bahwa golongan Majusi di perlakukan sama seperti kaumYahudi dan Nashrani, tidak ada bedanya apakah meraka akan menjadi Muslim atau tetap dalam agama aslinya. ${ }^{11}$

Sedangkan masa berlakunya, menurut para ahli sejarah, Piagam Madinah yang dibuat Nabi berjalan selama satu setengah abad, terhitung

${ }^{9}$ Hasan Ibrahim Hasan, Tarikh Al-Islam As-Siyasiy, Jil. I, Cairo: Maktabah An-Nahdah Al-Mishriyyah, 1945, dalam Ibid. hlm. 122

${ }^{10}$ Ibid. hlm. 122-124

${ }^{11}$ A. Anshari Ritonga, Pengantar Sejarah Perkembangan Hukum Islam dan Piagam Madinah, Jakarta: Pustaka El Manar, 2017, hlm. 116 
dari pembentukannya pada tahun I H (622 M) sampai runtuhnya Dinasti Umayyah dan berdirinya Abbasiyyah tahun $132 \mathrm{H}(750 \mathrm{M}) .{ }^{12}$

\section{Budaya}

Budaya sama halnya kebudayaan adalah sesuatu yang diletakkan kepada manusia, tanpa manusia budaya atau kebudayaan tidak akan terwujud. Kata kebudayaan dinisbatkan kepada kata dalam bahasa latin, cultura, yang mengandung pengertian memelihara, mengerjakan, atau mengolah. ${ }^{13}$

Dalam KBBI kata budaya berarti 1) pikiran; akal budi; 2) adat istiadat; 3) sesuatu mengenai kebudayaaan yang sudah berkembang (beradab, maju) ; 4) cak sesuatu yang sudah menjadi kebiasaan yang sudah sukar diubah. Sedangkan pengertian kebudayaan adalah 1) hasil kegiatan dan penciptaan batin (akal budi) manusia seperti kepercayaan, kesenian dan adat istiadat; 2) Antr keseluruhan pengetahuan manusia sebagai makhluk sosial yang digunakan untuk memahami lingkungan serta pengalamannya dan yang menjadi pedoman tingkah lakunya. ${ }^{14}$ Adapun definisi yang disebutkan para ahli sangat beragam, antara lain:

1. Edward Burnett Tylor, kebudayaan merupakan keseluruhan yang kompleks, yang di dalamnya terkandung pengetahuan yang lain, serta kebiasaan yang didapat seseorang sebagai anggota masyarakat.

2. R. Linton dalam bukunya "The Cultural Background of Personality", Kebudayaan adalah konfigurasi dari tingkah laku dan hasil laku, yang unsur-unsur pembentukannya didukung serta diteruskan oleh anggota masyarakat tertentu.

3. Melville J. Herskovits, Kebudayaan adalah " Man made part of the environment " (bagian dari lingkungan manusia).

4. Dawson (Age of The Gods), Kebudayaan adalah cara hidup bersama (culture is common way of life).

5. V.H. Deryvendak, Kebudayaan adalah kumpulan dari cetusan jiwa manusia sebagai yang beraneka ragam berlaku dalam suatu masyarakat tertentu.

\footnotetext{
${ }^{12}$ Zainal Abidin Ahmad, Piagam Madinah Konstitusi Tertulis..., hlm. 182

${ }^{13}$ Rusydi Sulaiman, Pengantar Metodologi Studi Sejarah Peradaban Islam, Jakarta: Rajawali Pers, 2014, hlm. 29

${ }^{14}$ Kamus Besar Bahasa Indonesia, Jakarta: Balai Pustaka, 1999, hlm. 149
} 
6. Sultan Takdir Alisyahbana, Kebudayaan adalah manifestasi dari cara berfikir

7. Dr. Moh. Hatta, Kebudayaan adalah ciptaan hidup dari suatu bangsa

8. Mangunsarkoro, Kebudayaan adalah segala yang bersifat hasil kerja jiwa manusia dalam arti yang seluas-luasnya

9. Drs. Sidi Gazalba, Kebudayaan adalah cara berfikir dan merasa yang menyatakan diri dalam seluruh segi kehidupan dari segolongan manusia yang membentuk kesatuan sosial dengan suatu ruang dan suatu waktu. ${ }^{15}$

Sedangkan dalam bahasa Arab menggunakan istilah tsaqafa. Bila dikatakan tsaqafa asy-sya'i maka itu artinya ia cepat sekali belajarnya. Secara terminologi tsaqafa berarti cara manusia di dalam kehidupannya, serta kemampuannya hidup di dalam bayang-bayang lingkungan dan kondisiyang dialaminya. Dengan demikian setiap manusia memiliki caranya (tsaqafa-nya) sendiri. ${ }^{16}$

A. Hasjmy menyimpulkan dari berbagai macam definisi kebudayaan adalah penjelmaan (manifestasi) akal dan rasa manusia; yang berarti manusialah yang menciptakan kebudayaan. Dengan demikian jika dikaitkan dengan Islam, maka kebudayaan Islam adalah penjelmaan akal dan rasa manusia Muslim, dan bersumber kepada manusia Muslim. Atau dengan kata lain kebudayaan Islam adalah manifestasi keimanan dan kebaktian dari penganut Islam sejati. ${ }^{17}$

\section{Unsur-Unsur Kebudayaan}

Substansi utama kebudayaan meruapakan wujud abstrak dari segala macam ide dan gagasan manusia yang bermununculan di dalam masyarakat yang memberi jiwa kepada masyarakat itu sendiri, baik dalam bentuk atau berupa: sistem pengetahuan, nilai, pandangan hidup, kepercayaan, persepsi, dan etos kebudayaan.

1. Sistem Pengetahuan

${ }^{15}$ Djoko Widagdho, Ilmu Budaya Dasar, Jakarta: Bumi Aksara, 2001, hlm.

${ }^{16}$ Muhammad Husain Mahasnah, Pengantar Studi Sejarah Peradaban Islam, Jakarta: Pustaka Al-Kautsar, 2016, hlm. 18 3

${ }^{17}$ A. Hasjmy, Sejarah Kebudayaan Islam, Jakarta: Bulan Bintang, 1995, hlm. 
Sistem pengetahuan yang dimiliki manusia sebagai makhluk sosial merupakan suatu akumulasi dari perjalanan hidupnya dalam hal berusaha memahami: Alam sekitar; Zat - zat bahan mentah, dan benda - benda dalam lingkungan; Sifat - sifat dan tingkah laku sesame manusia; dan ruang dan waktu.

Untuk memperoleh pengetahuan tersebut di atas manusia, maka melakukan tiga cara: pertama, melalui pengalaman dalam kehidupan sosial. Kedua, melalui pengalaman yang diperoleh dengan pendidikan. Ketiga, melalui petunjuk - petunjuk yang bersifat simbolis yang sering disebut sebagai komunikasi simbolis.

\section{Nilai}

Nilai adalah sesuatu yang baik selalu diinginkan, dicita - citakan dan dianggap penting oleh seluruh manusia sebagai anggota masyarakat. Oleh karena itu, sesuatu dikatakan memiliki nilai apabila berguna dan berharga (nilai kebenaran), indah (nilai estetika), baik (nilai - moral atau etis), dan religious (nilai agama).

\section{Pandangan Hidup}

Pandangan hidup merupakan pedoman bagi suatu bangsa atau masyarakat dalam menjawab atau mengatasi berbagai masalah yang dihadapinya. Di dalamnya terkandung konsep nilai kehidupan yang dicita - citakan oleh suatu masyarakat. Oleh karena itu, pandangan hidup merupakan nilai - nilai yang dianut oleh suatu masyarakat dengan dipilih secara selektif oleh individu, kelompok, atau bangsa.

4. Kepercayaan

Pada dasarnya, manusia memiliki naluri untuk menghambakan diri kepada yang Mahatinggi, yaitu dimensi lain di luar diri dan lingkungannya, yang dianggap mampu mengendalikan hidup manusia. Dorongan ini sebagia akibat atau refleksi ketidakmampuan manusia dalam menghadapi tantangan - tantangan hidup dan hanya yang Mahatinggi saja yang mampu memberikan kekuatan dalam mencari jalan keluar dari -permasalahan hidup dan kehidupan.

\section{Persepsi}

Persepsi atau sudut pandang ialah suatu titik tolak pemikiran yang tersusuh dari seperangkat kata - kata yang digunakan untuk memahami kejadian atau gejala dalam kehidupan. Persepsi terdiri atas; 1) Persepsi sensoris, yaitu persepsi yang terjadi tanpa menggunakan salh satu indra manusia; 2) persepsi telepati, yaitu kemampuan pengetahuan kegiatan 
mental individu lain; dan 3) persepsi clairvoyance, yaitu kemampuan melihat peristiwa atau kejadian di tempat lain, jauh dari tempat orang yang bersangkutan.

6. Etos Kebudayaan

Etos atau jiwa kebudayaan (dalam antropolog) bersal dari bahasa Inggris berarti watak khas. Etos sering tampak pada gaya perilaku warga misalnya, kegemaran - kegemaran warga masyarakat, serta berbaga benda budaa hasil karya mereka, dilihat dari luar oleh orang asing. ${ }^{18}$

\section{Wujud Kebudayaan}

Wujud kebudayaan adalah suatu rangkaian tindakan dan aktivitas manusia yang berpola. J.J. Honigmam dalam bukunya The World of Man (1959) membagi budaya dalam tiga wujud, yaitu: 1. Ideas, 2. Activities, 3. Artifact. Demikian juga Koentjaraningrat mengemukakan bahwa kebudayaan itu dibagi dalam tiga wujud:

1. Wujud sebagai suatu kompleks dari ide-ide, gagasan, nilai-nilai, norma-norma, dan peraturan.

Wujud tersebut menunjukkan wujud ide dari kebudayaan, sifatnya abstrak, tak dapat diraba dan tempatnya ada dalam pikiran warga masyarakat di mana kebudayaan yang bersangkutan itu hidup.

2. Wujud kebudayaan sebagai suatu aktivitas serta tindakan berpola dari manusia dalam masyarakat.

Wujud ini disebut sistem sosial, karena menyangkuttindakan dan kelakuan berpola dari manusia itu sendiri. Sistem sosial ini merupakan perwujudan kebudayaan yang bersifat konkrit, dalam bentuk perilaku dan bahasa.

3. Wujud kebudayaan berupa benda-benda hasil karya manusia. wujud ini juga disebut kebudayaan fisik, dimana hampir seluruhnya merupakan hasil fisik atau aktivitas perbuatan dan karya semua manusia dalam masyarakat. Sifatnya konkret dan berupa benda-benda atau hal-hal yang dapat diraba, dilihat. ${ }^{19}$

\footnotetext{
${ }^{18}$ Suratman dkk., Ilmu Sosial \& Budaya Dasar, Malang: Intimedia, 2013, hlm. 38-41

${ }^{19}$ Elly M. Setiadi dkk., Ilmu Sosial Budaya Dasar, Jakarta: Prenadamedia Group, 2012, hlm. 29-30
} 


\section{Peradaban}

Peradaban atau hadharah dalam bahasa Arab secara etimologi berasal dari kata hadharah yang berarti ada, daerah perkotaan. Kata hadhar (daerah perkotaan) merupakan kebalikan dari kata al-badwu (pedalaman). Sedangkan kata al-hadhir yang berarti sebutan bagi orang-orang yang bermukim di kota, yang merupakan kebalikan dari kata al-badi yang berarti sebutan bagiorang-orang yang tinggal di pedalaman. Adapun kata alhadharah berarti menetap di suatu tempat secara permanen. Definisi scara terminology adalah segala sesuatu yang berkaitan dengan kehidupan tetap manusia, meliputi sistempolitik, ekonomi, social, pemikiran dan kesenian. ${ }^{20}$

Para ahli telah banyak membincangkan tentang peradaban. Abul A'la Al-Maududi mengatakan, "Hadharah (peradaban) tidak lain hanyalah sebuah system yang integral, yang mencakup semua yang dimiliki oleh manusia, meliputi pemikiran, ide, tindakan, dan moral dalam kehidupan mereka, baik secara personal, keluarga, social, ekonomi, maupun politik. Sedangkan Durant meyatakan bahwa hadharah merupakan system sosial yang membantu seseorang meningkatkan produktivitas kebudayaannya. Sementara Toynbee berpendapat bahwa peradaban merupakan buah dari aktivitas manusia di ranah social dan moral. Ia meruapakan gerakan yang terus maju, bukan realita yang statis dan kaku. Ia tidak lain adalah perjalanan kehidupan yang terus berlangsung. ${ }^{21}$

\section{Asas-Asas Peradaban} bawah ini.

Peradaban manusia pada hakikatnya terbentuk karena asas-asas di

1. Konsep. Konsep atau ide, atau gagasan, atau ilmu dan lain sebagainya, adalah inti dari sebuah peradaban.

2. Pelaku. Konsep, tak peduli baik atau buruk, benar atau salah, bisa tegak dan muncul sebagai sebentuk peradaban karena ada (para) pelaku atau pendukungnya. Bila tidak, konsep hanya tinggal konsep. Mungkin hanya bisa lestari dalam bentuk tulisan di bukubuku dan berbagai media perekam yang lain.

3. Waktu dan tempat. Waktu dan tempat adalah sarana yang diperebutkan manusia untuk menegakkan sebuah konsep. Di sini

\footnotetext{
${ }^{20}$ Muhammad Husain Mahasnah, Pengantar Studi Sejarah..., hlm. 10-11

${ }^{21}$ Ibid, hlm. 12
} 
berlaku prinsip yang disamarkan Darwin menjadi teori evolusi fisik: survival for the fittests; yaitu bertahan hidup atau lestarinya individu-individu, kelompok-kelompok, bangsa-bangsa yang paling tangguh menghadapi tantangan hidup, dalam arti eksistensi peradaban yang diperjuangkan.

4. Prosedur. Setiap konsep pastilah memiliki prosedur atau tatacara pelaksanaan yang harus dioperasikan secara disiplin oleh para pelakunya. Bila tidak, peradaban yang dibangun tidak akan bisa mencapai puncak.

5. Proses. Proses yang dimaksud di sini adalah tahapan-tahapan yang harus ditempuh dan dilakukan oleh para pelaku dalam menuangkan konsep berdasar prosedur. ${ }^{22}$

\section{Perbedaan Kebudayaan dan Peradaban}

Pengertian peradaban dan kebudayaan dalam bahasa Indonesia sering kali dianggap sama, meski dalam bahasa inggris berbeda, yaitu kata civilization untuk peradaban dan culture untuk kebudayaan. Demikian juga dalam bahasa Arab kata hadharah untuk peradaban dan tsaqafah untuk kebudayaan.

Di kalangan para ahli sendiri membedakan definisi kedua istilah (peradaban dan kebudayaan) yang sering dicampuraadukkan, antara lain:

a. Bierens De Hann (1822-1895). Mempertentangkan pengertian kebudayaan dan peradaban sebagai berikut. Peradaban adalah seluruh kehidupan sosial, politik, ekonomi, dan teknik. Jadi peradaban adalah bidang kehidupan untuk kegunaan yang praktis, sedangkan kebudayaan ialah sesuatu yang berasal dari hasrat dan gairah yang lebih dan murni yang berada di atas tujuan yang praktis hubungan kemasyarakatan.

b. Oswald Spengl (1880-1936) mengatakan bahwa kebudayaan ialah wujud dari seluruh kehidupan adat, industrial filsafat dan sebagainya, sedangkan peradaban ialah kebudayaan yang sudah tidak tumbuh lagi sudah mati.

c. Koentjaraningrat (1923-1999), mengatakan bahwa peradaban ialah bagian-bagian kebudayaan yang halus dan indah, seperti kesenian. $^{23}$

${ }^{22}$ https://ahmadhaes.wordpress.com/2011/03/25/asas-asas-peradaban/

${ }^{23}$ Elly M. Setiadi dkk., Ilmu Sosial Budaya Dasar..., hlm. 47-48 
Suatu hal yang membedakan antara kebudayaan dan peradaban sebenarnya terletak pada kemajuan dan kesempurnaan wujud tertentu yang telah dicapai seseorang atau masyarakat. Jadi, kebudayaan mencakup juga peradaban, tetapi tidak sebaliknya, sebab peradaban dipakai untuk menyebut kebudayaan yang maju dalam bentuk ilmu pengetahuan, tekhnologi dan seni. Dalam pengertian kebudayaan direfleksikan kepada masyarakat yang terbelakang, bodoh, sedangkan peradaban terefleksikankan pada masyakarat yang sudah maju. ${ }^{24}$

\section{HASIL DAN DISKUSI}

\section{Piagam Madinah Sebagai Dasar Budaya dan Peradaban}

Piagam Madinah dikatakan sebagai konsep budaya dan peradaban karena memang naskah ini dibuat oleh Nabi Shallallahu 'Alaihi wa Sallam sebagai aturan, norma dan nilai yang harus menjadi tuntunan masyarakat Madinah dalam berinteraksi satu dengan yang lainnya. Sekaligus menjadi dasar semua anggota masyarakat dalam berkarya, berkreasi, berinovasi dalam mengembangkan diri baik secara individu maupun sosial. Oleh karena itu dalam sub bahasan ini penulis akan menguraikan aplikasi pelaksanaan Piagam Madinah sehingga menjadi sebuah konsep budaya dan peradaban.

\section{Masyarakat Yatsrib Sebelum Piagam Madinah}

Secara geografis, kota ini datar yang dikelilingi gunung dan bukitbukit serta beriklim gurun. Madinah merupakan pusat pemukiman masyarakat Arab yang telah ada sebelum agama Islam datang. Nama pemukiman tersebut adalah Yatsrib. Dalam pandangan masyarakat Arab, Yatsrib tidak mempunyai kedudukan apa-apa. Ia tidak sepenting kedudukan kota Makkah yang di dalamnya terdapat Baitullah yang disakralkan oleh seluruh masyarakat Arab.

Dilihat dari komunitas sosialnya, penduduk Madinah sangat herterogen. Secara keseluruhan, penduduk Madinah terdiri dari sebelas kelompok. Delapan kelompok itu berasal dari bangsa Arab. Adapun yang paling dominan di antara mereka ada dua suku yaitu klan (suku) Khazraj dan Aus yang berasal dari Arab bagian selatan. Mereka adalah masyarakat 2018, hlm. 3

${ }^{24}$ Syamruddin Nasution, Sejarah Peradaban Islam, Jakarta: Rajawali Pers, 
yang menguasai lahan pertanian di Madinah. ${ }^{25}$ Selain delapan kelompok bangsa Arab tersebut, terdapat juga tiga kelompok asing yang tinggal di Madinah. ${ }^{26}$ Mereka adalah orang-orang Yahudi yang berhijrah ke Jazirah Arabia sejak abad pertama Masehi. ${ }^{27}$ Mereka lebih menguasai dunia perdagangan karena mereka tinggal di pusat pemukiman Yatsrib. ${ }^{28}$

Hanya saja, sangat disayangkan sifat heterogenitas masyarakat Madinah ternyata tidak dapat meredam sifat keangkuhan primordialisme yang melekat pada masing-masing kelompok. Akibatnya, hampir setiap hari konflik antar suku senantiasa muncul dalam kehidupan mereka. Bahkan, konflik tersebut sering dianggap sebagai hal yang biasa. Konflik yang terus berkepanjangan membawa dampak lambannya perkembangan tingkat peradaban masyarakat Madinah. ${ }^{29}$

Sebagai contoh permusuhan yang turun temurun dan bahkan sudah menjadi kebencian yang mendarah daging antara Kabilah Aus dan Khazraj, walaupun pada dasarnya mereka masih dalam satu ikatan kekerabatan. Tetapi karena permusuhan itu sedemikian hebatnya, anakanak mereka pun sejak lahir hingga dewasa sudah dinyatakan bermusuhan. ${ }^{30}$

Konflik yang paling genting adalah konflik yang terjadi pada tahun 617-8 M yang dikenal dengan nama konflik Bu'ats. Konflik Bu'ats adalah

${ }^{25}$ Tanah kota Yatsrib sangat subur untuk bercocok tanam, itulah sebabnya kebanyakan penduduknya menyandarkan hidupnya dari bercocok tanam. Hasil utamanya adalah buah kurma, anggur dan sayur mayur. Jika musim hujan hasil kebun penduduk Yatsrib sangat melimpah sehingga diguanakan sebagai alat tukar menukar penggantui uang. Lihat Abu Hasan Ali Al-Hasany An-Nadwy, As-Sirah AnNabawiyyah, Terj. Bey Arifin, Surabaya: Bina Ilmu, 1983. hlm. 165

${ }^{26}$ Mereka adalah suku Nadir, Qainuqa, dan Quraizhah, yang waktu itu diperkirakan jumlah lelaki dewasa mereka lebih dari 2000 (dua ribu) orang.

${ }^{27}$ Setelah berakhirnya peperangan antara bangsa Yahudi dan bangsa Romawi di tahun $70 \mathrm{M}$ dengan hancurnya Palestina dan pusat peribadatan Yahudi di Baitul Maqdis. Sehingga banyak bangsa Yahudi terpencar ke seluruh pelosok dunia, termasuk sebagian besar mereka berhijrah ke Jazirah Arab. Lihat Dr. Israil Velavonson, Al-Yahudu Fi biladil Arabi Fil Jahiliyyati Wa Shadril Islam, Kairo: AlI'timaad, 1927, hlm. 9, yang dikutip oleh Abu Hasan Ali Al-Hasany An-Nadwy, AsSirah An-Nabawiyyah, hlm. 151

${ }^{28} \mathrm{http}: / /$ suara-muhammadiyah.com/2009/?p=595

${ }^{29}$ Ibid.

${ }^{30}$ Muhammad Al-Ghazali, Fiqhus Sirah, Cairo: Darul Kutub Al-Hadits, 1967. Hlm. 152 
konflik yang melibatkan hampir seluruh kelompok masyarakat Madinah. Konflik ini berawal dari semakin merosotnya peranan orang-orang Yahudi dalam kehidupan perkonomian masyarakat Madinah. Mereka mengalami dinamika kehidupan yang ditandai dengan terjadinya pergeseran peranan di antara kelompok yang ada. Keadaan ini segera dipahami oleh dua suku Arab yang paling berpengaruh, yaitu Khazraj dan Aus. Mereka akhirnya, saling berebut kedudukan untuk menggantikan posisi peranan orang-orang Yahudi dalam dunia perekonomian, perdagangan, dan kontrol terhadap pasar. ${ }^{31}$

Dari segi keadaan kepercayaan penduduk Yatsrib sebelum kedatangan Islam adalah sama dengan masyarakat Arab pada umumnya, yang menyembah berhala dengan mengikuti tatacara kaum Quraisy. Hanya saja kepercayaan penduduk Yatsrib tidak sekuat penduduk Makkah dalam kepercayaan ini, sebab tidak kita temukan keterangan yang mengatakan bahwa penduduk kota Yatsrib mempunyai patung khusus buat mereka saja, seperti Laata, Manat, uzza dan Hubal yang disembah penduduk Makkah. Pada umumnya mereka hanya menyembah patung-patung besar di luar kota Yatsrib. ${ }^{32}$

\section{Pelaksanaan Piagam Madinah}

Di tengah kemajemukan penghuni kota Madinah, Muhammad Shallallahu 'Alaihi wa Sallam berusaha membangun tatanan hidup bersama dan mencakup semua golongan yang ada di kota Madinah. Sebagai langkah awal beliau membangun masjid. Di dalam masyarakat Islam masjid berkedudukan sebagai pusat pembinaan mental spiritual dan phisik material, tempat berhubungan dengan Tuhan sepanjang zaman, yang akan melahirkan hubungan yang kokoh antara hamba dengan Tuhannya dan akan menjadi sumber kekuatan individu-individu Muslim. Bagaimana tidak kaum muslimin diwajibkan melakukan kejama'ahan shalat fardu yang lima di masjid-masjid, dan shalat jum'at berjama'ah setiap minggu. Kejam'ahan shalat di masjid inilah yang akan membentuk jama'ah (masyarakat) Islam yang solid, menjadi kultur (adat istiadat) perkampungan kaum muslimin,

\footnotetext{
${ }^{31} \mathrm{http}: / /$ suara-muhammadiyah.com/2009/?p=595,

${ }^{32}$ Abu Hasan Ali Al-Hasany An-Nadwy, As-Sirah An-Nabawiyyah, hlm. 161163
} 
sehingga terwujud masyarakat yang "la khaufun 'alaihim walahum yahzanun". ${ }^{33}$

Masjid itu bukan sekedar tempat untuk melaksanakan shalat semata, tetapi juga menjadi sekolah bagi orang-orang Muslim untuk menerima pengajaran dan bimbingan-bimbingan Islam, sebagai balai pertemuan dan tempat untuk mempersatukan berbagai unsur kekabilahan dan sisa-sisa pengaruh perselisihan semasa Jahiliyah, sebagai tempat untuk mengatur segala urusan dan sekaligus sebagai gedung parlemen untuk bermusyawarah dan menjalankan roda pemerintahan. ${ }^{34}$

Dan juga sistem Islam adalah terpadunya beraneka ragam latar belakang kaum muslimin dalam satu kesatuan yang kokoh diikat oleh tali Allah, ini pun bisa dilakukan bila masjid-masjid telah dibangun ditengah masyarakat muslim, karena masjid adalah tempat kaum muslimin beerkumpul mempelajari ajaran Islam. ${ }^{35}$

Langkah selanjutnya, Rasulullah Shallallahu 'Alaihi wa Sallam mempersaudarakan para sahabatnya dari kaum Muhajirin dan Anshar. ${ }^{36}$ Sebab masyarakat manapun, tidak akan berdiri tegak, kokoh tanpa adanya kesatuan dan dukungan anggota masyarakatnya. Sedangkan dukungan dan kesatuan tidak akan lahir tanpa adanya persaudaraan dan saling mencintai. Suatu masyarakat yang tidak disatukan oleh tali ikatan kasih sayang dan persaudaraan yang sebenarnya, tidak mungkin bersatu pada satu prinsip. Persaudaraan itu harus didasari oleh aqidah yang menjadi idiologi dan faktor pemersatu. Persaudaraan antara dua orang yang berbeda aqidah

33 HM Shalahuddin Sanusi, Pembangunan Masyarakat Masjid; Format Pembangunan Berparadigma Surgawi, Sukabumi: Lembaga Pembinaan 'Imaratul Masajid, 2003. hlm. 110

34 Syaikh Shafiyyur Rahman Al-Mubarakfury, Ar-Rahiqul Maktum, Bahtsun Fis-Sirah An-Nabawiyah Ala Shahibiha Afdhalish-Shalati Was-Salam, hlm. 185

${ }^{35}$ Muhammad Sa'id Ramadhan Al-Buthy, Sirah Nabawiyah, Jakarta: Rabbani Press, 2001, hlm. 171

${ }^{36}$ Ibnu Ishak berkata: di antara yang di persaudarakan adalah Abu Bakar ashShiddiq dengan Kharijah bin Zuhair, Umar bin Khattab dengan Utbah bin Malik, Abdurrahman bin Auf dengan Sa'ad bin Rabi, Ammar bin Yasir denganhudzaifah bin Yaman, Abu Dzar dengan al-Munzir bin Amr, Hamzah bin Abdul Muthalib dengan Zaid bin Haritsah, Bilal bin Raba dengan Abu Ruwaihah Abdullah bin Abdurrahman al-Khats'ami dan sahabat-sahabat lainnya yang mencapai 90 orang. Lihat Ahzami Samiun Jazuli, Hijra dalam Pandangan Al-Qur'an, Jakarta: Gema Insani Press, 2006. hlm. 262 
adalah mimpi dan khurafat. Oleh sebab itu Rasulullah menjadikan aqidah Islamiyah yang bersumber dari Allah swt. Sebagai asas persaudaraan yang menghimpun hati para sahabatnya. ${ }^{37}$

Inilah di antara buah yang dihasilkan dari perjalanan hijra yang dilakukan oleh Rasulullah dan para sahabatnya. Pelajaran yang paling berharga bagi nilai kemanusiaan dari peristiwa ini adalah pengorbanan, pembelaan, dan itsar (mendahulukan kepentingan orang lain). Dasar dari persaudaraan yang dilakukan oleh Rasulullah ini tidak memandang perbedaan suku, ras, dan status sosial. Rasulullah memandang sama mereka yang merupakan bangsa Arab maupun non-Arab. Antara orang yang bebas dan seorang budak. Antara seorang tokoh pada suatu kabilah dengan orang biasa, dan antara orang kaya dan miskin. ${ }^{38}$

Persaudaraan yang dilakukan oleh Rasulullah diantara kaum muslimin tersebut tidak hanya antara Muhajirin dan Anshar saja, tetapi lebih luas dari itu, yakni dilakukan antara semsama orang-orang Muhajirin, dan sesama orang-orang Anshar. Hal ini dilakukan oleh Rasulullah dengan maksud merekatkan hubungan antara kabilah-kabilah kaum Muhajirin dan lebih khusus merekatkan hubungan suku Aus dan suku Khazraj yang sering berperang sebelum kedatangan Rasulllah ke Madinah. Menurut Imam Abdur Rahman al-Khats'ami dalam kitabnya Ar-Raudhul Unuf menyebutkan: "maksud dari persaudaraan ini adalah untuk menghilangkan kesepian lantaran meninggalkan kampung halaman mereka, dan menghibur karena berpisah dengan keluarga, disamping agar mereka saling membantu satu sama lain". ${ }^{39}$

Untuk melihat gambaran kedekatan dan itsar di antara mereka. Allah SWT menggambarkannya dengan indah dalam al-Qur'an, surat alhasyr ayat 9 :

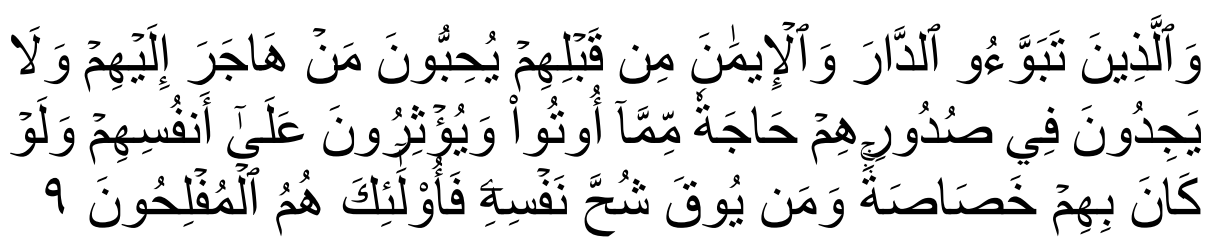

${ }^{37}$ Muhammad Sa'id Ramadhan Al-Buthy, Sirah Nabawiyah... hlm. 176-177

38 Ahzami Samiun Jazuli, Hijra dalam Pandangan Al-Qur'an, hlm.261-262

${ }^{39}$ Ahmad Shalaby, Masyarakat Islam, Jogyakarta: tanpa penerbit, 1957. hlm. 41-42 
"Dan orang-orang yang telah menempati kota Madinah dan telah beriman (Anshor) sebelum (kedatangan) mereka (Mubajirin), mereka (Anshor) 'mencintai' orang yang berbijrah kepada mereka (Mubajirin). dan mereka (Anshor) tiada menaruh keinginan dalam hati mereka terhadap apa-apa yang diberikan kepada mereka (Mubajirin); dan mereka mengutamakan (orang-orang mubajirin), atas diri mereka sendiri, Sekalipun mereka dalam kesusahan. dan siapa yang dipelihara dari kekikiran dirinya, mereka Itulah orang orang yang beruntung." (Q.S. Al-Hasyr:9)

Rasulullah menjadikan persaudaraan Muhajirin dan Anshar sebagai asas bagi prinsip-prinsip keadilan sosial yang paling baik di dunia. Prinsipprinsip ini kemudian berkembang dan mengikat menjadi hukum-hukum dan undang-undang syari'at yang tetap, yang berbasis pada ukhuwah islamiyah.

Setelah Rasulullah mengokohkan persatuan kaum Muslimin, dan telah berhasil memancangkan sendi-sendi masyarakat Islam yang baru, dengan menciptakan kesatuan aqidah, politik dan sistem kehidupan di antara orang-orang Muslim, maka langka selanjutnya yang dilakukan oleh Rasulullah adalah menawarkan perjanjian damai kepada golongan atau pihak di luar Islam. Perhatian beliau pada saat itu adalah bagaimana menciptakan keamanan, kebahagiaan dan kebaikan bagi semua manusia, mengatur kehidupan di daerah itu dalam satu kesepakatan. ${ }^{40}$

Secara garis besar perjanjian antara Rasulullah dengan golongan di luar Islam yang kemudian dikenal dengan nama Piagam Madinah, dapat disebutkan beberapa klausul pentingnya berikut pendahuluannya:

"Bismillabir rabmanir rabim. Ini adalah perjanjian Muhammad, Nabi yang Ummi, untuk kaum mukminin dan Muslimin dariQuraisy dan Yatsrib, juga untuk siapa pun yang mengikuti,bergabung, dan berjihad bersama mereka, bahwa mereka adalah satu umat."

4. Orang-orang Mukmin tidak membiarkan seorang pun di antara mereka menanggung beban hutang dalamjumlah besar seorang diri. Mereka harus menolongnya dengan cara yang baik, baik hutang tersebut berupa tebusan maupun diyat.

${ }^{40}$ Syaikh Shafiyyur Rahman Al-Mubarakfury, Ar-Rahiqul Maktum, Bahtsun FisSirah An-Nabawiyah Ala Shahibiha Afdhalish-Shalati Was-Salam, hlm. 192 
5. Orang mukmin tidak dibenarkan menjalin persekutuan dengan hamba sahaya seorang mukmin tanpa melibatkan si mukmin tersebut.

6. Orang-orang mukmin yang bertakwa saling melindungi terhadap siapa pun yang bermaksud berbuat kezhaliman, kejahatan, atau merusak hubungan diantara sesama kaum mukminin. Mereka bersatupadu melawannya, sekalipun itu anak salah seorang dari mereka sendiri.

7. Seorang Mukmin tidak boleh membunuh orang Mukmin lainnya lantaran ia membunuh seorang kafir. Seorang Mukmin tidak boleh membantu orang kafir untuk melawan Mukmin lainnya. Perlindungan Allah itu satu, bisa diberikan hingga kepada yang paling rendah tingkatannya diantara mereka.

8. Orang-orang mukmin membela satu sama lain diantara seluruh manusia. Siapaun diantara kaum Yahudi yang mengikuti kami, iaberhak mendapat pembelaan dan teladan, tanpa dizalimi atau pun diserang.

9. Perdamaian Orang-orang mukmin itu satu. Orang mukmin tidak menjalin hubungan damai tanpa melibatkan mukmin lain dalam peperangan di jalan Allah, kecuali harus adil di antara mereka.

10. Siapa membunuh mukmin dengan sengaja, ia harus diqishash kecuali jika wali korban merelakan, dan seluruh orangorang mukmin harus menegakkan qishas kepadanya.

11. Orang-orang Yahudi membantu Orang-orang mukmin selama mereka berperang. Sesungguhnya orang-orang Yahudi Bani Auf satu Umat dengan Orang-orang mukmin. Yahudi dan kaumMuslimin berhak menjalankan agama masing-masing, juga para pendukung dan diri mereka masing-masing, kecuali yang berbuat zalim ata pun kesalahan, yang membinasakan diri sendiri dan keluarganya.

12. Orang-orang Yahudi ada kewajiban biaya sendiri dan bagi kaum muslimin ada kewajiban biaya sendiri. Mereka saling membantu dalam menghadapi siapapun yang memerangi pihakpihak yang terikat dalam perjanjian ini. Mereka saling tulus dan saling menasehati. Seseorang tidak bersalah karena kesalahan yang dilakukan sekutunya. Orang teraniaya berhak ditolong, dan 
tetanggasama seperti diri sendiri, tanpa membahayakan ataupun berbuat kesalahan.

13. Setiap Mu'min yang telah mengakui berlakunya perjanjian ini, jika ia benar-benar beriman kepada Allah swt dan hari Akhir niscaya ia tidak akan memberikan pertolongan dan perlindungan kepada orang yang berbuat kejahatan. Apabila ia menolong dan melindungi orang yang berbuat kejahatan maka ia terkena laknat dan murka Allah swt pada hari Kiamat. Amal wajib maupun sunnahnya tidak diterima.

14. Apapun yang kalian perselisihkan harus dikembalikan kepada Allah swt dan Muhammad Shallallahu 'Alaihi wa Sallam utusan Allah. ${ }^{41}$

\section{Prinsip-Prinsip Bermasyarakat dalam Piagam Madinah}

Konsep dasar yang tertuang dalam Piagam Madinah lahir di masa NabiMuhammad Shallallahu 'Alaihi wa Sallam merupakan pernyataan maupun sikap dari kesepakatan masyarakat Madinah guna melindungi serta menjamin hak-hak sebagai sesama warga masyarakat Madinah tanpa melihat latar belakang, baik suku, ras, agama maupun warna kulit.

Terdapat dua pokok prinsip yang terkandung dalam piagam Madinah sebagai pegangan kehidupan bermasyarakat majemuk dan beragam baik suku, ras, bangsa dan agama yang dipimpin Nabi Muhammad Shallallahu 'Alaihi wa Sallam.

1. Semua pemeluk beragama yang ada di Madinah merupakan satu umat walaupun terdapat perbedaan baik suku maupun bangsa.

2. Hubungan antara komunitas muslim dan non-muslim didasarkan pada prinsip-prinsip:

a. Berinteraksi dan berkomunikasi dengan baik sesama warga atau tetngga

b. Saling bahu membahu serat saling membantu dalam menghadapi musuh yang akan merongrong kota Madinah

c. Membela terhadap yang lemah dan teraniaya

d. Saling nasehat menasehati dalam koridor kebersamaan dan kebenaran

${ }^{41}$ Syaikh Abu Bakar Jabir Al-Jaza'iri, Sirah Nabawiyah Versi Tadabbur, Solo: Zamza,2016, hlm. 196-197 
e. Saling menghargai dan menghormati serta memberikan toleransi dalam menentukan pilihan dalam beragama/kebebasan beragama. ${ }^{42}$

Setelah disepakatinya Piagam Madinah sebagai aturan hidup bersama, maka sejak itu Islam menjadi nilai, norma dan pandangan hidup yang berlaku di Madinah, seluruh warga dibimbing oleh nilai-nilai yang terkandung dalam piagam tersebut.

M. Natsir menulis Islam sebagai sumber kebudayaan. Karena unsur-unsur risalah yang dibawah oleh Nabi Muhammad Shallallahu 'Alaihi wa Sallam menjadikan pemeluknya manusia budaya. Islam mendorong bahkan mewajibkan kaum muslimin untuk menuntut ilmu yang akan menjadikan mereka berkualitas tinggi disisi Allah dan manusia. Dilarangnya orang berilmu menyembunyikan ilmunya dan diwajibkannya mereka menyampaikan ilmu.

Islam merangsang daya observasi untuk memperhatikan dan meneliti alam semesta, demikian juga daya fikir dirangsang untuk memikirkan apa yang berada dibelakang semua fenomena yang dapat dilihat, didengar dan dirasa. Kaum muslimin dihadapkan pada pertanyaanpertanyaan retoris yang menggugah:

"Apakah mereka tidak memperhatikan?"

"Maka Apakah mereka tidak merenungkan?"

"Apakah Kamu tidak menggunakan akal?"

Islam juga merangsang orang beriman agar jangan hidup ibarat katak di dalam tempurung, seorang mukmin dipanggil oleh Islam, risalah Nabi Muhammad Shallallahu 'Alaihi wa Sallam agar hidup dalam kesadaran akan ruang dan waktu, sanggup menilai sesuatu dalam perspektif sejarah. Demikian juga Islam telah meletakkan hubungan yang tepat antara manusia dengan alam sekitarnya, yang merupakan sumber kehidupan baginya:

42 Jamal Ghofir, Nilai Toleransi Dalam Dakwah Nabi Muhammad SAW, Yogyakarta: Dialektika, 2017, hlm. 59-60 
kepada alam tumbuh-tumbuhan, hewan, kekayaan bumi, lautan dan bendabenda langit.

Nilai-nilai hidup inilah yang pada akhirnya menjadikan manusia lebih tinggi martabatnya, dan berkebudayaan tinggi. ${ }^{43}$

\section{KESIMPULAN}

Dengan terbentuknya masyarakat Islam pertama dibawah bimbingan Nabi Muhammad Shallallahu 'Alaihi wa Sallam dengan segala perangkatnya di Madinah, maka dapatlah ditegaskan bahwa masyarakat tersebut adalah masyarakat dengan konsep modern pertama di dunia. Semua unsur-unsur masyarakat modern yang dikenal sekarang ada pada masyarakat Madinah, mulai dari tata aturan pergaulan hingga perundangundangan yang diberlakukan dalam kehidupan bermasyarakat. Langkahlangkah strategis yang dilakukan Rasulullah dalam membentuk masyarakat Madinah menunjukkan bahwa tatanan sosial dalam Islam jauh berbeda bahkan bertolak belakang dengan tatanan sosial kapitalis maupun konsepkonsep masyarakat lainnya yang diperkenalkan Barat.

Nilai-nilai Islam yang berlaku dalam kehidupan masyarakat Madinah itulah yang kemudian mendasari terbentuknya kebudayaan dan peradaban yang tinggi. Diantara nilai-nilai tersebut adalah bahwa Islam menghapuskan kebodohan (buta huruf), membina daya cipta masyarakat, membina bakat dan potensi sehingga seimbang lahir dan batinnya, seimbang ilmu dan akhlaknya, seimbang ikhtiar dan do'anya. Dengan demikian seharusnya ini menjadi kesadaran semua pihak dalam melakukan pengembangan dan pembinaan masyarakat, senantiasa merujuk dan mencontoh bagamana Rasulullah Shallallahu 'Alaihi wa Sallam mengembangkan dan membina masyarakat Madinah.

\section{DAFTAR PUSTAKA:}

Ahmad, Zainal Abidin, (2014). Piagam Madinah Konstitusi Tertulis Pertama di Dunia, Jakarta: Pustaka Al-Kautsar

Al-Buthy, Muhammad Sa’id Ramadhan, (2001) Sirah Nabawiyah, Jakarta: Rabbani Press

${ }^{43}$ M. Natsir, Kebudayaan Islamdalam Perspektif Sejarah, Jakarta:

Girimukti Pasaka, 1988, hlm. 323-328 
Al-Ghazali, Muhammad, (1967). Fiqhus Sirah, Cairo: Darul Kutub AlHadits

Al-Jaza'iri, Syaikh Abu Bakar Jabir, (2016). Sirah Nabawiyah Versi Tadabbur, Solo: Zamza

Al-Mubarakfury, Syaikh Shafiyyur Rahman, (1999). Ar-Rabiqul Maktum, Babtsun Fis-Sirah An-Nabawiyah Ala Shabibiha Afdhalish-Shalati WasSalam, Beirut: Muassasah Arrisalah

An-Nadwy, Abu Hasan Ali Al-Hasany, (1983). As-Sirah An-Nabawiyyah, Terj. Bey Arifin, Surabaya: Bina Ilmu

Ghofir, Jamal, (2017). Nilai Toleransi Dalam Dakwah Nabi Mubammad SAW, Yogyakarta: Dialektika

Hafidhuddin, Didin, (2004 ). Islam Aplikatif, Jakarta: Gema Insani

Hasjmy, A., (1995). Sejarah Kebudayaan Islam, Jakarta: Bulan Bintang

Jazuli, Ahzami Samiun, (2006). Hijra dalam Pandangan Al-Qur'an, Jakarta: Gema Insani Press

PusatPembinaan dan Pengembangan Bahasa, (1999). Kamus Besar Bahasa Indonesia, Jakarta: Balai Pustaka

Mahasnah, Muhammad Husain, (2016). Pengantar Studi Sejarab Peradaban Islam, Jakarta: Pustaka Al-Kautsar

Nasution, Syamruddin, (2018 ). Sejarah Peradaban Islam, Jakarta: Rajawali Pers

Natsir, M., (1988). Kebudayaan Islamdalam Perspektif Sejarah, Jakarta: Girimukti Pasaka

Ritonga, A. Anshari, (2017) Pengantar Sejarah Perkembangan Hukum Islam dan Piagam Madinah, Jakarta: Pustaka El Manar

Sanusi, HM Shalahuddin, (2003). Pembangunan Masyarakat Masjid; Format Pembangunan Berparadigma Surgawi, Sukabumi: Lembaga Pembinaan 'Imaratul Masajid

Setiadi, Elly M. dkk., (2012) Ilmu Sosial Budaya Dasar, Jakarta: Prenadamedia Group

Shalaby, Ahmad, (1957) Masyarakat Islam, Jogyakarta: tanpa penerbit 
Sukardja, Ahmad, (2012) Piagam Madinah \& Undang-Undang Dasar NRI 1954, Jakarta: Sinar Grafika

Sulaiman, Rusydi, (2014) Pengantar Metodologi Studi Sejarah Peradaban Islam, Jakarta: Rajawali Pers

Suratman dkk., (2013). Ilmu Sosial \& Budaya Dasar, Malang: Intimedia

Widagdho, Djoko, (2001). Imu Budaya Dasar, Jakarta: Bumi Aksara

https://www.neliti.com/

http://suara-muhammadiyah.com

https://ahmadhaes.wordpress.com 